\title{
Microeconomics
}

Georgios L. THANASAS, Vassilis S. SMARAIDOS

\section{CREATIVE ACCOUNTING IN GREEK FOOTBALL CLUBS}

\begin{abstract}
Football Clubs tent to manipulate their profits in order to obtain a license to participate in Championships, organized under the supervision of UEFA. This article examines, whether Football Clubs that compete in the Greek Super League and in European Competitions use earnings management techniques to manipulate their profits. In order to do so, Jones' (1991) modified econometric model was used to estimate the accruals that determine the level of earnings management, for the period 2013-15. The statistical analysis, which performed with the use of STATA statistical package v.13, show that Greek Football Clubs which compete in European Competitions are more effective in manipulating their profits while Football Clubs which compete in Greek Super League and have difficulties in obtaining a license do not appeal to manipulate their profits.
\end{abstract}

\section{Key words:}

Creative Accounting, Earnings Management, Football Clubs, Greece.

(C) Georgios L. Thanasas, Vassilis S. Smaraidos, 2017.

Thanasas Georgios L., PhD, University of Patras - Dept. Business Administration of Food and Agricultural Enterprises.

Smaraidos Vassilis S., PhD Candidate, University of Patras - Dept. Business Administration of Food and Agricultural Enterprises. 
JEL: M40, M41.

\section{Introduction}

Recently, all Europe Football Leagues have been widely debated the fact that, due to reduction in television broadcasting revenues, ticket sales and sponsorships compare to high debts in their annual financial results, are in financial difficulty. For example, the Dutch Premier League lost 89.5 million Euros in the season 2009/2010. Ajax lost about 22.8 million Euros, PSV lost about 17.5 million Euros, Heerenveen lost 14.9 million Euros and Feyenoord 14 million Euros. Although, two seasons earlier, these Clubs were still profitable with a total profit of 64 million.

UEFA introducing Financial Fair Play aspires to put an end to overpayment, to inflated transfer fees and to excessive wages that players earn. These rules require more budgetary discipline and more rational economic behavior of the Football Clubs, while encourage them to act responsibly so as to spent less than they earn. The above rules are designed to make European Football healthy and sustainable in the long term, as long as to be a safety net for the integrity and the proper function of Competitions. Moreover, UEFA aims to encourage the long term investment by developing the academies and the sport facilities. The development and the implementation of the above rules did not come as a surprise. Approximately $65 \%$ of Football Clubs revenue was spent on wages, while about $47 \%$ of the Football Clubs reported losses.

The negative economic environment, at this time, considered appropriate for manipulating accounting results and economic sizes of the Football Clubs. According to Healy and Wahlen (1999), earnings management occurs when company managers use their judgment during the preparation of the annual financial reports either when they plan to give information to shareholders in regard to actual firm performance, or to influence the firm contracts that depend on the published stock sizes.

According to Scott (2009), earnings management consists of accounting policies and actual actions of the firm. These accounting policies are divided into two categories; the first one refers to the accounting policies, such as the choice of the straight line method of depreciation against the others. The second category refers to the discretionary accruals, such as provisions for credit losses, the cost of inventory valuation and the time when the amounts of non-operational 
and abnormal costs occur and are being book kept. In addition, profits are managed through real actions, such as the time that a purchase or a sale is being done, the advertising costs, the R\&D costs and the costs of repairs and maintenance.

In Greece, the Football Clubs that took part on professional competitions are Ltd Companies and act according to Law 2190/1920 «About Ltd Companies». The Football Clubs in Greece are called PAE (Podosfairiki Anonimi Etairia). In order a Football Club to secure a participation in the Super League, it is essential to have a license by the Professional Football Committee EPO (Association of Football Federations).

The criteria for the above license in order to participate in the Super League are five:

\section{Athletic \\ 2. Managerial \\ 3. Financial \\ 4. Infrastructure \\ 5. Legally}

The Financial Criteria refer to the preparation of the annual financial statements, which should be audited by independed auditors. Additionally there should be no financial obligations to other Clubs or athletes made before December 31 of the year preceding the year in which the application of the Club is submitted. Furthermore, a submission of a business plan, for the future performance of the Club should be made. This business plan should presume the possibility for the continued activity of the Football Club and that it does not maintain a negative equity position.

\section{Literature Review}

Nowadays, Football Clubs have been transformed into businesses and their activities can be easily compared to those with profit status (Frank, 2010). According to this, a worldwide width on literature is developed the last years, so as to investigate the phenomenon of earnings management in the football sector.

Healy and Whalen (1999), argue that one of the most important parameter in earnings management is the legislation. This fact is in favor at countries such as Greece, because of the multidisciplinary tax system and the multiplicity of the regulations that exist. Leuz et al (2003), examined the financial statements of 8000 companies from 31 countries, during a decade and concluded that earnings 
management varies from country to country due to differences in their institutional characteristics. Another important fact that conclude the above researchers, concerns the inherent relationship between corporate governance and the quality of reported profits. Leventis and Dimitropoulos (2012), in their study on US Banking System, conclude that a strong corporate governance is accompanied by less business engagement with profit - sharing practices.

Ronen and Sadan (1981), mention that managers can either rationalize revenues by dividing the effect of accounting transactions over time, by modifying the revenues for specific periods, or by classifying non-recurring funds. Furthermore, Healy and Wahlen (1999), Fudenberg and Tirole (1995), as well as Dechow and Skinner (2000), denote that earnings management can be done through faster sales, shifting product timetables, reducing R\&D costs and costs of maintenance.

Additionally, Trueman and Titman (1988), argue that sometimes managers choose to rationalize revenues, thus their businesses present a less risky investment than it actually is. Although earnings management does not violate any of the accounting rules and is therefore considered to be legal, Abdelghany (2005) notice that this act is not entirely moral, as it denotes that the distortion of the truth is not necessarily bad.

In 2011, Dinopoulos investigate the relationship of corporate governance along with earnings management in 67 Clubs participating in the European Competitions for the period 2006-2009, regarding the size of the Board of Directors, its independence and the quality of the CEO as well with the ownership of the Club. He also found that the quality of corporate governance mitigated the manipulation of profits. In order to measure the quality of profits he used a model introduced by Kothari.

\section{Methodology}

\section{The Sample}

The Super League is the top athletic men category of football in Greece and it ends after 16 games. In the Greek Super League, 16 Football Clubs compete. For the purpose of this study Football Clubs that compete in the Super League of Greece for the season 2016-2017 were chosen and their financial statements for the years 2012-2015 is analyzed. From the sample of the study, «PAE AEK» and «PAE Larisa» where exclude, because these two Clubs are start-up companies and therefore it is not possible to apply to the econometric 
model. In order to reduce the risk of heteroskedasticity, all the variables are divided to Total Assets of the previous year. The fiscal year for the PAE begins on July $1^{\text {st }}$ and expires on June $30^{\text {th }}$ of the following year.

\section{Estimation of earnings management}

In order to estimate earnings management, the modified econometric model of Jones (1991) is used. All statistical analysis is made with the statistical package STATA v. 13. The total accruals initially estimated using the following formula:

$$
\frac{\text { TAit }}{\text { Ait }-1}=a 1\left(\frac{1}{\text { Ait }-1}\right)+a 2\left(\frac{\Delta R E V i t}{\text { Ait }-1}\right)+a 3\left(\frac{P P E i t}{\text { Ait }-1}\right)+\varepsilon i t
$$

Equation 1: The formula for calculating total accruals.

Where:

TAit: total accruals, Ait - 1: total assets, $\triangle R E V i t:$ change in sales and PPEit: fixed assets.

After calculating the parameters of Equation 1 for the years 2013 to 2015 separately, the non-managed accruals (NDAit) calculated as follows:

$$
N D A i t=a 1\left(\frac{1}{A i t-1}\right)+a 2\left(\frac{\Delta R E V i t-\Delta R E C i t}{A i t-1}\right)+a 3\left(\frac{P P E i t}{\text { Ait }-1}\right)
$$

Equation 2: The calculation of non-manageable accruals.

Where:

$\triangle R E C i t$ change in liabilities.

In order to calculate the accruals (DAit), Equation 3 was taken into account. This is the main ratio for measuring accruals in accordance to earnings management.

$$
\text { DAit }=\frac{\text { TAit }}{\text { Ait }-1}-N D A i t
$$

Equation 3: Calculation of accruals that can be manipulated. 


\section{The Research Hypothesis}

For the purpose of this study, the sample will be divided into two main categories; firstly the PAEs who have difficulty obtaining a license to participate Super League in the current season and secondly those one that receive or have taken part in the European Competitions in the current season.

In total, six (6) PAEs were unable to obtain a license from the Professional Sports Committee (EPO), or they received it after objection. These are PAE Heraklis, PAE Veroia, PAE Levadiakos, PAE PAS Giannina, PAE Platanias and finally PAE Panionios which did not managed to obtain license. In order to obtain a license, a PAE should meet the criteria mention above and especially the financial one. For that reason, PAE have an interest to manipulate its financial results upwards in order not to produce any debts.

It is essential to mention that four of the Greek Football Clubs participate in the European Collective Events (PAE Olympiakos, PAE Panathinaikos, PAE PAOK, PAE PAS Giannina). These Football Clubs were asked to receive additional UEFA's membership approval and to meet the criteria of Financial Fair Play.

According to the above, the research hypothesis made is:

HO: Football Clubs with difficulty in obtaining a license to participate in the Championship tend to manipulate their profits more strongly than the rest of the Football Clubs.

H1: Football Clubs that participate in European Competitions tend to manipulate their profits more strongly than the rest of the Football Clubs. 


\section{Results}

Table 1, shows the results for the a1, a2 and a3 variables of the two multiple regression models that was analyzed in order to calculate the non-managed accruals

Table 1

Multiple regression estimators

\begin{tabular}{|c|c|c|c|c|c|c|}
\hline & \multicolumn{3}{|c|}{$H_{0}$} & \multicolumn{3}{c|}{$H_{1}$} \\
\cline { 2 - 7 } & 2013 & 2014 & 2015 & 2013 & 2014 & 2015 \\
\hline$R^{2}$ & 0,8345 & 0,4514 & 0,9934 & 0,9803 & 0,7765 & 0,631 \\
\hline$F$ & 5,04 & 8,2 & 200,32 & 66,31 & 15,4232 & 13,42 \\
\hline Const & 0,4399727 & $-0,0840575$ & $-0,5424025$ & $-0,1872183$ & 0,32825 & $-0,9035586$ \\
\hline $1 / A_{t-1}$ & 392237,5 & 298032 & 469886,3 & 946322,5 & $-644024,5$ & 602059,7 \\
\hline $\begin{array}{c}(\Delta \text { Sales - } \\
\begin{array}{c}\Delta \text { Receivables }) / \\
A_{t-1}\end{array}\end{array}$ & $-1,488348$ & $-0,3306904$ & $-0,2112059$ & $-0,3059378$ & 0,3782746 & $-0,2979024$ \\
\hline$P P E / A_{t-1}$ & $-0,7003292$ & $-0,0840575$ & $-0,5424025$ & 0,0534854 & $-0,5123706$ & $-0,9035586$ \\
\hline
\end{tabular}

In general the two models seem to have high predictive capability, thus the $R^{2}$ receiving high values. The two first variables seem to be statistically significant at $95 \%$ level.

For both hypothesis the assumption that $\mu_{D A}>0$ is examined, that if it is statistically significant so whether there is upward management for higher profits.

Table 2

\section{$t$-test results}

\begin{tabular}{|c|c|c|c|c|c|c|}
\hline & $N$ & Mean & Std. Deviation & Std. Error Mean & $t$ & Sig. \\
\hline$H_{0} D A$ & 16 & 1.774789 & 6.89456 & 1.72364 & 1.0297 & 0.1597 \\
\hline$H_{1} D A$ & 12 & 0.5547018 & 0.9261834 & 0.2673661 & 2.0747 & 0.0311 \\
\hline
\end{tabular}


According to Table 2, for the sample examined, the $H_{0}$ hypothesis is rejected. Football Clubs that face difficulties in obtaining a license do have a high average of managed accruals, hence these Clubs do not tend to manipulate their profits ( $p$-value $0.1597>0.05)$.

For the $\mathrm{H}_{1}$ hypothesis, Table 2 shows that cannot be rejected ( $p$-value $0.0311<0.05$ ). Thus, Greek Football Clubs that compete in the European Competitions tend to use techniques of earnings management for their profits.

\section{Conclusions}

The purpose of this article is to study whether the Greek Football Clubs manipulate their profits in order to be eligible to participate in the championship or to qualify for participation in UEFA Events. The financial data of all Football Clubs that participate on the Greek Super League was taken into account. From the sample, AEC FC and Larisa FC were excluded, due to the fact that both of them published financial statements for only a year, so the econometric model for these two Football Clubs cannot be applied. For the analysis, Jones' modified econometric model was used.

According to the study, Herakles FC, Veria FC, Levadiakos FC, Panionios FC, PAS Giannina FC and Platanias FC, teams that had difficulties in obtaining a license to participate in the Greek Super League for the season 201617 , is not statistically significant to manipulate their profits in general. Although the fact that some Football Clubs do have a negative net position, which is a negative factor to obtain a license from the EPO Committee, as well as a reason for bankruptcy according to the Greek Law (2190/20, article 47), does not constitutes a fear. On the other hand, Olympiakos FC, Panathiaikos FC, PAOK FC and Pas Giannina FC, teams that were invited to represent Greece in European Competitions, seem to strongly manipulate their profits upwards, as a fact of UEFA's strict conditions of Financial Fair Play.

Finally, in the future, the sample could be expanded to more years and for more Football Clubs, taking into account teams that compete in the second league, since this league is also included in the professional category. By that, the future research may potentially give more secure conclusions about case of manipulating their profits. 


\section{References}

1. Ball, R., \& Shivakumar, L. (2005). Earnings quality in UK private firms: Comparative loss recognition timeliness. Journal of Accounting and Economics, $\sigma \sigma .83-128$.

2. Baralexis, S. (2004). Creative accounting in small advancing countries - The Greek case. Managerial Auditing Journal, oб. 440-461.

3. Burgstahler, D., \& Dichev, I. (1997). Earnings management to avoid earnings

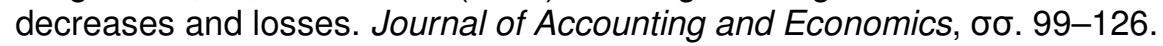

4. Coppens L., Peek, E. (2005). An analysis of earnings management by European private firms. Journal of international accounting, auditing and taxation, $\sigma \sigma .1-17$.

5. Dimitropoulos, P. (2011). Corporate Governance and Earnings Management in the European Football Industry. European Sport Management Quarterly, бo. 495-523.

6. Franck, E. (2010). Private firm, public corporation or member's association governance structures in. International Journal of Sport Finance, or. 108127.

7. Goncharov, I., \& Zimmermann, J. (2006). Earnings management when incentives compete: The role of tax accounting in Russia. Journal of International

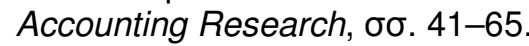

8. Gore, P., Pope, P., \& Singh, A. (2006). Earnings management and the distribution of earnings relative to targets: UK evidence. Accounting and Business Research, $\sigma \sigma .123-150$.

9. Healy, P., \& Wahlen, J. (1999). A Review of the Earnings Management Literature and Its Implications for Standard Setting. Accounting Horizons, бб. 365-383.

10. Jones, J. (1991). Earnings management during import relief investigations.

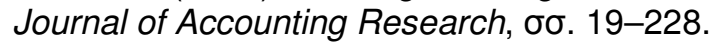

11. Kothari, SP, Leone, AJ and Wasley, CE. (2005). Performance matched discretionary accrual measures. Journal of Accounting and Economics, бo. 163-197.

12. Kousenidis D. , Ladas A. , Negakis, C. (2013). The effects of the European debt crisis on earnins quality. International Review of Fanancial Analysis, $\sigma \sigma .351-362$.

13. Lo, K. (2008). Earnings management and earnings quality. Journal of Accounting and Economics, $\sigma \sigma .350-357$. 
14. Othman, H., Zeghal, D. (2006). A study of earnings-management motives in the Anglo-American and Euro-Continental accounting models: The Canadian and French cases. The international journal of accounting, $\sigma \sigma .406-435$.

15. Scott, W. (2009). Financial Accounting Theory. Toronto: Pearson.

16. Trombetta M. , Imperatore C. (2014). The dynamic of financial crises and its non-monotonic effects on earnings quality. J. Account. Public Policy, 205232. 